\title{
HUMORAL IMMUNE RESPONSE IN CATTLE EXPERIMENTALLY INFESTED WITH LARVAE OF DERMATOBIA HOMINIS
}

\author{
RESPOSTA IMUNE HUMORAL EM BOVINOS INFESTADOS \\ EXPERIMENTALMENTE COM LARVAS DE DERMATOBIA HOMINIS
}

\author{
Celso Guimarães Barbosa ${ }^{1}$ Argemiro Sanavria ${ }^{2}$ Ronald Bastos Freire ${ }^{3}$
}

\section{SUMMARY}

Six bovines were infested with 60 first instar larvae of Dermatobia hominis. The animals were bleed weekly, and their antibodies levels to $D$. hominis $L_{1}, L_{2}$ and $L_{3}$ instars measured during the time, following the infestation course. The antisera were submitted to a titration against optimal dilutions of antigen coated wells of microplates, previously sensitized with $L_{1}$, $L_{2}$ and $L_{3}$ preparations, respectively. The ELISA assay was used to test single dilutions of antisera, which results were comparatively analyzed with a control of not infested animals. Antibodies against $L_{l}$ were detected between the first and $21^{\text {st }}$ day postinfestation (DPI) and, from the $42^{\text {nd }}$ DPI on. Anti- $L_{2}$ antibodies, could be detected on the $21^{\text {st }}$ DPI and from the $35^{\text {th }}$ DPI until approximately the $49^{\text {th }} \mathrm{DPI}$, when it was observed a decreasing of antibodies titration equivalent to the control group. No antibodies were detected against the $L_{3}$ instar-antigens. Antibodies levels against $L_{1}$ showed absorbance higher than 1.500 O.D. at $492 \mathrm{~nm}$ in the ELISA assay, when compared to the 0.096 O.D. observed to the negative animals. High anti- $L_{2}$ antibodies were also detected on the $21^{\text {st }} \mathrm{DPI}$, where two animals showed O.D. of 0.450 and 0.900 at $492 \mathrm{~nm}$, with a cut-off estimated on 0.110 O.D. It was also demonstrated a rising of anti- $L_{2}$ antibodies in the same four animals, which presented antibodies response against $L_{l}$ instar. The obtained results, with an estimated prevalence of 50\%, were comparatively evaluated, taking the double diffusion immunoassay precipitation test as a standard, and showed a concordance of $98 \%$. The association between infestation and presence of specific antibodies was also discussed.

Key words: Dermatobia hominis, myiasis, humoral immune response, ELISA.

RESUMO

Foram estudadas as alterações imunológicas em um grupo de seis bovinos infestados, experimentalmente, com 60

\begin{abstract}
larvas de primeiro ínstar $\left(L_{1}\right)$ de Dermatobia hominis por animal, enquanto que outro grupo de seis animais foi utilizado como controle. Amostras de sangue tomadas, semanalmente, durante a infestação experimental, foram analisadas para se detectar anticorpos anti- $L_{1}$, anti- $L_{2}$ e anti- $L_{3}$ de $D$. hominis, utilizando-se a técnica de ELISA, na qual utilizou microplacas contendo amostras de soro dos animais e preparações antigênicas de $L_{1}, L_{2}$ e $L_{3}$. Observou-se nos animais infestados, o aparecimento de anticorpos anti- $L_{I}$ desde o primeiro até o $21^{o}$ dia pós-infestação (DPI) e após o $42^{\circ} \mathrm{DPI}$, enquanto que os anticorpos anti- $L_{2}$ foram detectados no $21^{\circ}$ DPI, e no período do $35^{\circ}$ ao $49^{\circ} \mathrm{DPI}$, seguido de declínio até atingirem valores semelhantes aos animais controles. Não se detectaram níveis expressivos de anticorpos para antígenos de $L_{3}$. Os níveis de anticorpos anti- $L_{1}$ dos animais infestados revelaram absorbância (D.O.) alta, ou seja, acima de 1,500 a 492nm quando comparado ao valor médio de 0,096 obtido nos animais controles, o que também ocorreu com os níveis de anticorpos anti- $L_{2}$ no $21^{\circ} \mathrm{DPI}$, nos quais dois animais apresentaram valores de D.O. de 0,450 e 0,900 a 492nm, em relação ao valor discriminante (cut-off) estimado em 0,110 dos animais controles. Verificou-se um aumento dos níveis de anticorpos anti- $L_{2}$ em quatro animais que também apresentaram resposta contra antígenos de $L_{1}$. Os resultados obtidos com a técnica de ELISA, pressupondo-se uma prevalência de 50\%, quando comparados com a técnica padrão de imunodifusão dupla, revelaram uma concordância de $98 \%$. Discutiu-se ainda a associação entre infestação e presença de anticorpos específicos.
\end{abstract}

Palavras-chave: Dermatobia hominis, miíase, resposta imune humoral, ELISA.

\section{INTRODUCTION}

Dermatobia hominis (LINNAEUS Jr., 1781), known in Brazil as "berne" fly, is distributed

${ }^{1}$ Professor Adjunto, PhD., em Parasitologia Veterinária, Universidade Federal Rural do Rio de Janeiro, BR 465, km 7, CP 74506, 23851-

970, Seropédica, RJ, Brasil. E-mail: celsogb@ufrrj.br. Autor para correspondência.

${ }^{2}$ Professor Adjunto, PhD. em Parasitologia Veterinária, Universidade Rural do Rio de Janeiro, RJ.

${ }^{3}$ Professor Adjunto, PhD em Parasitologia Veterinária, Universidade Federal Rural do Rio de Janeiro, RJ.

Recebido para publicação em 27.11.98. Aprovado em 11.08.99 
in Latin America's tropical and subtropical regions and is one of the most important ectoparasites infesting domestic animals. Its importance in cattle breeding is related to the economic losses caused by its larval forms (ANDERSEN, 1960; LELLO et al., 1982; SANCHO, 1988). Generally the life cycle of D. hominis in cattle last 35 days, but it varies according to environmental conditions and to the host, and might extend to over 100 days (LELLO et al., 1982).

The larval development of this fly includes first $\left(\mathrm{L}_{1}\right)$, second $\left(\mathrm{L}_{2}\right)$, and third $\left(\mathrm{L}_{3}\right)$ instars, growing from 1 to $25 \mathrm{~mm}$ in length and 0.3 to $10 \mathrm{~mm}$ in width, producing nodules that are easily detected in the host. The literature is limited regarding the host's immune response to this parasite. MOTA et al. (1980) has demonstrated that the larval antigens of $\boldsymbol{D}$. hominis are immunogenic in rabbits, whereas anti-D. hominis antibodies were detected up to 13 weeks post infestation (WPI). CORONADOFONSECA (1989) has observed an increase in $\boldsymbol{D}$. hominis antibody titres in cattle up to day 12 post infestation (DPI), suggesting a secondary immune response. LELLO et al. (1980) observed inflammatory reactions caused by $\boldsymbol{D}$. hominis larvae in rabbits that had been immunized. They verified that the inflammatory reactions surrounding the parasite occured earlier and with greater intensity in immunized rabbits.

This study represent the first ELISA investigation of the kinetics of the bovine humoral immune response to $\boldsymbol{D}$. hominis. The aim of this paper was to verify the evolution of the immune response on non-immunized cattle infested with larvae of this parasite.

\section{MATERIAL AND METHODS}

Raising of $\boldsymbol{D}$. hominis $\mathrm{L}_{1}$ larvae was carried out on the Institute of Veterinary at Universidade Federal Rural do Rio de Janeiro, Brazil. Frequent collections of $\mathrm{L}_{3}$ from naturally infested cattle were made from hide of cattle slaughtered as well as by extracting the warble from living cattle. $\mathrm{L}_{3}$ weighing, over $400 \mathrm{mg}$, were placed in glass flasks, containing moistened sawdust, and kept in an incubator (Fanem, Brazil) at $25 \pm 2^{\circ} \mathrm{C}$ with $70 \pm 10 \%$ relative humidity. After a period of 26 to 31 days, emerged adults were placed inside wood cages and allowed to mate. Adults of Musca domestica (L.), the housefly, were also placed inside the cage and served as vectors for the oviposition of $\boldsymbol{D}$. hominis adult females. In each cage a ratio of 10 to $30 \mathrm{D}$. hominis adults to 50 to 100 carrier insects was used. The housefly vectors serving as carriers of $\boldsymbol{D}$. homi- nis eggs were captured, conditioned in assay tubes and placed in an incubator under the conditions previously mentioned. After the incubation period, which varied from 4 to 6 days, the $L_{1}$ already at the phase of hatching were kept in an incubator at $20 \pm$ $1^{\circ} \mathrm{C}$, until the experimental animal infestation.

Twelve crossbred (Bos taurus x Bos indicus) male calves free from infestation by D. hominis were used which aged 12 to 18 months and weighted 120 to $140 \mathrm{~kg}$. The calves were kept in a stable for an adjustment period of 25 days fed on commercial concentrated feed (Purina brand), chopped "elephant" grass (Pennisetum purpureum, Schum.), and fresh water ad libitum. They were treated with levamisol chlorohydrate (Ripercol, Cyanamid) at $1 \mathrm{ml} / 20 \mathrm{~kg}$ l.w. and sprayed with deltametrin (Butox, Hoechst). After 25 days post drugs treatment, infestation was carried out. At this period, the calves were randomized in two groups of six calves, a control group (non-infested) and an infested group. Infested animals were held and their hairs removed on different spots of the dorsal region. The infestation methodology used was the same as carried out by SANAVRIA et al. (1987), wherein the $\mathrm{L}_{1}$ were encouraged to hatch and were individually removed with a thin point paintbrush and placed on the dorsal area of the calves. Calves were infested with $60 \mathrm{~L}_{1}$ of $\boldsymbol{D}$. hominis per calf.

The animals were bleed in the mornings of days $-7,0,7,14,21,28,35,42,49$, and 63 after infestation. Blood collection was made by jugular venipuncture, and after clotting, sera were obtained by centrifugation at $3000 \mathrm{rpm}$ for 10 minutes. Sera samples were frozen at $-20^{\circ} \mathrm{C}$ until use.

The ELISA (Enzyme-Linked Immunosorbent Assay) was carried out according classic methodology previously described (SÁNCHEZVISCAÍNO \& CAMBRA-ALVAREZ, 1987; CROWTHER, 1995, 1998). Antigens were obtained by processing $\boldsymbol{D}$. hominis larvae of three different ages: $\mathrm{L}_{1}$ newly-emerged from eggs, $\mathrm{L}_{2}$ (14 days) and $\mathrm{L}_{3}$ (28 days) obtained from cattle artificially infested. $\mathrm{L}_{1}$ antigens were prepared by sonication of $\mathrm{L}_{1}$ at $50 \mathrm{~Hz}$ in saline solution $(0.85 \%)$ for 30 minutes (Fisher, USA). $\mathrm{L}_{2}$ and $\mathrm{L}_{3}$ antigens were prepared by cutting larvae on Petri plates, followed by homegenization in saline solution $(0.85 \%)$ with a homegenizer (Virtis, USA) at 20,000 rev/min for $20 \mathrm{~min}$ utes. After 12 hours at $5^{\circ} \mathrm{C}$, homogenate was filtered and protein concentrations was determined by methodology described elsewhere (HUDSON \& HAY,1989). Bovine albumin (Merck) was used as the protein standard. Purified antigenic preparations were frozen at $-20^{\circ} \mathrm{C}$ until required, without any addictive. 
Polystyrene microtiter plates, with 96 flatbottom wells, were sensitized by the addition of $100 \mu \mathrm{l}(2.0 \mu \mathrm{g} / \mathrm{ml})$ of each of the three antigens diluted in carbonate buffer, $\mathrm{pH}$ 9.6, into each well and incubated at $5 \pm 1{ }^{\circ} \mathrm{C}$ overnight. The sensitized plates were washed twice with PBS $0.01 \mathrm{M}, \mathrm{pH} 7.2$ with tween 20 (polyoxyethylene sorbitan monolaurate, Vetec, Brazil) $0.05 \%$ (PBS-T) and dried for posterior use. Sensitized plates could be used for approximately 30 days when maintained at $4^{\circ} \mathrm{C}$. Test sera were diluted 1:500 in PBS-T containing 1\% powdered milk, instead of casein, for blocking irrelevant spaces, according methodology previously described (CROWTHER, 1998). Each serum was added to $100 \mu \mathrm{l}$ into each well in triplicate. Plates were incubated at $37 \pm 1^{\circ} \mathrm{C}$ for 45 minutes in a humid incubator, then washed three times with PBS-T. The anti-bovine conjugate (FIOCRUZ-RJ) diluted at 1:500 was added to $100 \mu \mathrm{l}$ into each well. The reaction was incubated at $37 \pm 1{ }^{\circ} \mathrm{C}$ for 45 minutes in a humid incubator. The plates were then washed for three times with PBS-T and, $100 \mu$ l of substrate (phosphate-citrate buffer, $\mathrm{pH} 3.5$, orthophenylenediamine and hydrogen peroxide, Merck) added to each well. The material was kept in the dark for 15 minutes. Color development (absorbance) was read at 492nm in a ELISA-reader (Labsystems, USA). The negative samples, obtained from the control group, constituted of not infested animals, served as a tool for constructing a cut-off, which was based on the average added of two standard deviations for each assessed antigen. A value higher than the cut-off was considered as a really positive. The obtained results were comparatively studied taking precipitation by double immune diffusion as a standard method (CROWTHER, 1995). The correlation of copositivity and co-negativity was evaluated. The independent variants were also estimated (TOMAN, 1981).

Assays with animals were planned considering a two-way design (infestation status - either present or absent - and periods of evaluations) and six replications per treatment. For assessment of the results regarding the levels of antibodies anti- $\mathrm{L}_{1}$, anti- $\mathrm{L}_{2}$ and ant $-\mathrm{L}_{3}$ of $\boldsymbol{D}$. hominis, the following statistic evaluations were done: ANOVA, Tukey's test and polynomial regression analysis (SNEDECOR \& COCHRAN, 1976).

\section{RESULTS AND DISCUSSION}

The main aim of this paper was to establish an immunoassay to measure bovine antibodies, which could react against antigenic preparations obtained from different instars of $\boldsymbol{D}$. hominis. For this reason, it was established two groups of animals: the first one, constituted of six bovines which were experimentally infested with $60 \mathrm{~L}_{1}$; and the second, with six control animals, which were not infested at this time. The animals were bleed weekly, and their antibodies levels against soluble antigens of $\boldsymbol{D}$. hominis $\mathrm{L}_{1}, \mathrm{~L}_{2}$ and $\mathrm{L}_{3}$ instars measured during the time, following the infestation course of the experimentally inoculated animals. The antisera were submitted to a titration against optimal dilutions of antigen coated wells of microplates, previously sensitized with $\mathrm{L}_{1}, \mathrm{~L}_{2}$ and $\mathrm{L}_{3}$ preparations, respectively. The reacting antibodies detection was carried out by addition of a constant amount of an antispecie conjugate. Such assays were evaluated fully, from the diagnostic point of view where numbers of animals and experimental antisera, from each experimental group were available. Therefore, the ELISA assay was used to test single dilutions of antisera, and the tests could be adequately controlled using standard positive and negative antisera (CROWTHER, 1995, 1998). The averages of levels of antibodies anti- $\mathrm{L}_{1}$, anti- $\mathrm{L}_{2}$ and anti- $\mathrm{L}_{3}$ of $\boldsymbol{D}$. hominis observed in the infested animals are found in figure 1 . The averages of $\mathrm{L}_{1}$ and $\mathrm{L}_{2}$ preparations, expressed in absorbance values at $492 \mathrm{~nm}$, as observed in the infested animals, were significantly higher $(\mathrm{P}<0.01)$ than those observed in the control animals. Although it was observed a great variation on the antibodies levels from the experimentally infested group, the anti- $\mathrm{L}_{1}$ and anti- $\mathrm{L}_{2}$ qualities could be detected in different periods postinfestation. Antibodies against $\mathrm{L}_{1}$ were detected during the period between the first and $21^{\text {st }}$ day postinfestation (DPI) and, from the $42^{\text {nd }}$ DPI on. Anti- $\mathrm{L}_{2}$ antibodies, by their turn, could be detected on the $21^{\text {st }}$ DPI and from the $35^{\text {th }}$ DPI until approximately the $49^{\text {th }}$ DPI, when it was detected a decreasing of antibodies titration which were equivalent to the control group. No antibodies were detected against the $\mathrm{L}_{3}$ instar-antigens on the evaluated period. Some infested animals presented a tendency of rising antibodies levels against $\mathrm{L}_{1}$ and $\mathrm{L}_{2}$ antigenic preparations. Such phenomena was noticed, manly to the $\mathrm{L}_{1}$ instar, where four animals showed very high antibodies levels, whose absorbance was higher than 1.500 O.D. at $492 \mathrm{~nm}$ in the ELISA assay, when compared to the cut-off, estimated in 0.096 O.D. Except for two animals, which did not present circulating antibodies, all the others infested animals were always positive against the $\mathrm{L}_{1}$ instar. Nevertheless, between the $21^{\text {st }}$ and $28^{\text {th }}$ DPI period and, on the $42^{\text {nd }} \mathrm{DPI}$, they presented results very close related to the cut-off as well as the control animals. High anti- $\mathrm{L}_{2}$ antibodies were also detected on the 


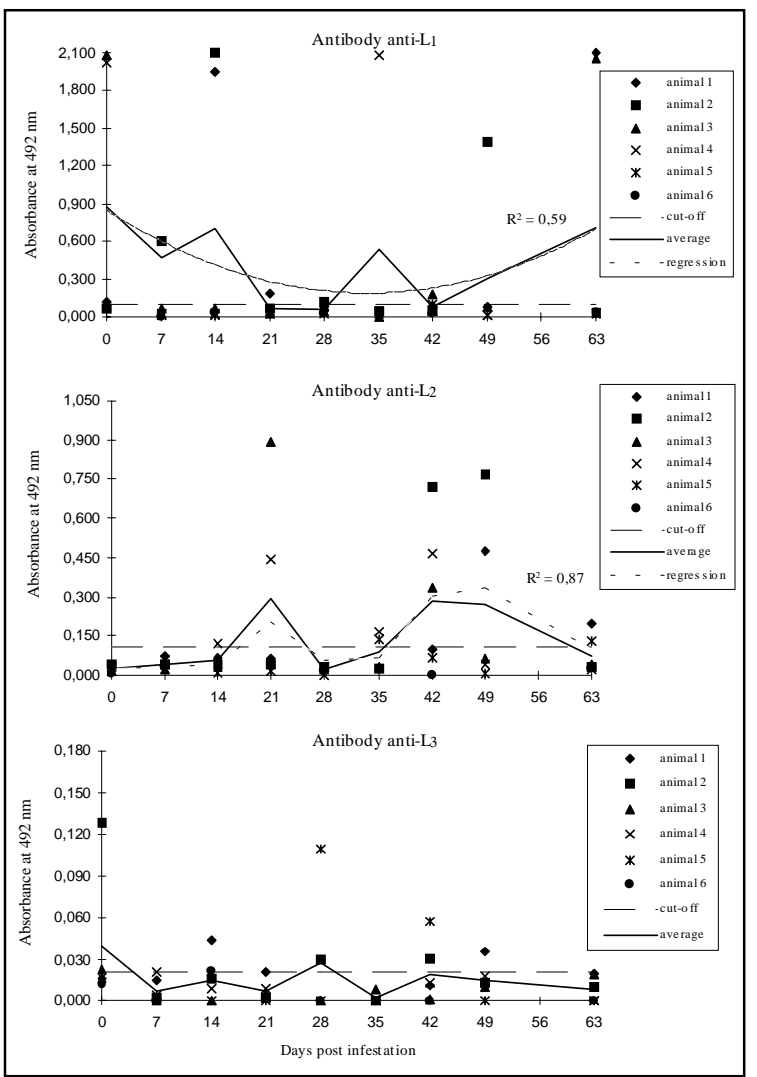

Figure 1 - Averages of levels of antibodies anti- $\mathrm{L}_{1}$, anti- $\mathrm{L}_{2}$ and anti- $\mathrm{L}_{3}$ of Dermatobia hominis observed in the infested animals.

21st DPI, where two animals showed O.D. of 0.450 and 0.900 at $492 \mathrm{~nm}$, respectively, with a cut-off estimated on 0.110 O.D. It was also demonstrated a rising of anti- $\mathrm{L}_{2}$ antibodies in the same four animals, which presented antibodies response against $\mathrm{L}_{1}$ instar, on the $42^{\text {nd }}$ and $49^{\text {th }}$ DPI, when titration were higher than 0.300 O.D. The obtained results, with an estimated prevalence of $50 \%$, were comparatively evaluated, taking the double diffusion immunoassay precipitation test as a standard, and showed a concordance of $98 \%$. On the other hand, the predictive values of sensitivity, specificity and accuracy, suggested that ELISA assay against different instars of D. hominis $\left(\mathrm{L}_{1}\right.$ and $\left.\mathrm{L}_{2}\right)$ should be of relevance to epidemiological studies, carried out at large incidence regions. The high specificity $(95 \%)$ of the antigenic preparations showed a positive predictive value of $86 \%$. Such value risen according to the estimated occurrence of positive animals: $93 \%$ to a $70 \%$ prevalence and $98 \%$ to a prevalence of $90 \%$. Otherwise, its accuracy could be assured manly in low incidence regions, whose prevalence should be estimated below $50 \%$, when the accuracy was $60 \%$.
Taking on consideration that a good accuracy to this method should be higher than $70 \%$, it should be of great utility in a $37 \%$ prevalence region. In spite of this, more detailed studies have to be made in order to identify better antigenic preparations, once the estimated sensitivity was only $28 \%$. There is a need of a strong research base to obtain scientific insights and valuable reagents to allow more routine applications. The method outlined shows the flexibility of the experimental systems. Recent advances in science have given ways to improving the sensitivity and specificity of the ELISA assay to $\boldsymbol{D}$. hominis instars. It should be pointed out that the ability to develop ELISA against the different instars depends on a closer understanding on the immunologicalserological-biochemical knowledge of the highest antibodies affinity of antigenic markers present in the antigenic preparations used (ROGAN, 1997). Such experiments have been made, actually, at our laboratories. It was noticed that three infested animals presented antibodies against $\mathrm{L}_{1}$ and $\mathrm{L}_{2}$ instars before infestation. Although such results suggest similar determinants could be presented in both, $\mathrm{L}_{1}$ and $\mathrm{L}_{2}$ preparations, once the tested sera were submitted to 1:500 dilutions before assaying in order to avoid cross reactions, there is a possibility of previous contact. The total absence of similar results on the control group corroborates with this last hypothesis, once these animals were restrained and free of infestations for a long period of time. The presence of one animal which presented antibodies against the $\mathrm{L}_{3}$ instar at 28 DPI should be related to a cross reaction, or any contaminant of different instar present during the antigen preparation. Other possibility should be related to the presence of reactive antibodies to the $\mathrm{L}_{3}$ instar, which development occurred independently of the other instars, once such transformations were not synchronized on each infested animal. Previous work on D. hominis adaptive immune response on cattle showed the same tendency, with $90 \%$ of the animals presenting antibodies against $\boldsymbol{D}$. hominis prior to experimental infestation (CORONADO-FONSECA, 1989). SANDEMANN et al. (1995), as well as BARON \& NELSON (1985), seeking for antibodies titres to Lucilla cuprina and Melophagus ovinus, respectively, in experimentally infested sheep observed gradual augments of serum antibodies, which decreased on few weeks after exposition. These authors concluded that adaptive immune response against $\boldsymbol{L}$. cuprina and $\boldsymbol{M}$. ovinus should occurs only when larval infestation was active. Similar results were obtained by PERAÇOLI et al. (1980), LELLO \& BOULARD (1990) and LELLO \& PERAÇOLI (1993) working with rabbits experi- 
mentally infested with $\boldsymbol{D}$. hominis. The present study has a significant importance concerned to the capability of making specific antibodies following a D. hominis infestation, independent of class or isotype, which lasted for two months. Such immune response, although needing more detailed work on the antigenic components of each larval instar, suggests the $\mathrm{L}_{1}$ antigen as a representative marker to infestation on bovines, once there was a straight correlation between infestation and presence of specific antibodies. These levels of antibodies suggest that the antigens produced by $\mathrm{L}_{1}$ were more immunogenic than those produced by the other larval instars. The observed average of antibodies titration against $\mathrm{L}_{1}$ was 0.373 (O.D.). Such average was significantly higher $(\mathrm{P}<0.05)$ than those observed for

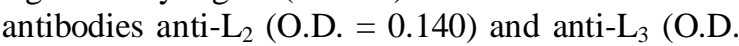
$=0.013)$. Finally, it can be concluded that ELISA against $\boldsymbol{D}$. hominis larval antigens is an important tool for studies of occurrence of infestations in different regions and periods of time.

\section{REFERENCES}

ANDERSEN, E.H. Biology, distribution and control of Dermatobia hominis. Veterinary Medicine, Chicago, v.55, n.1, p.72-78, 1960.

BARON, R.W., NELSON, W.A. Aspects of the humoral and cell-mediated immune response of sheep to the ked Melophagus ovinus (Diptera: Hippoboscidae). Journal of Medical Entomology, Lanham, v.22, n.5, p.544-549, 1985.

CORONADO-FONSECA, A.J. Aspectos imunológicos, atividade antibacteriana e efeito de várias doses de ivermectina sobre larvas de Dermatobia hominis. Itaguaí RJ, 1989. 23p. Dissertação (Mestrado em Parasitologia Veterinária) - Curso de Pós-graduação em Medicina Veterinária, Universidade Federal Rural do Rio de Janeiro, 1989.

CROWTHER, J.R. ELISA - theory and practice. In: WALKER, J.M. Methods in molecular biology. New Jersey : Humana, 1995. V.42. p.1-114.

CROWTHER, J.R. Enzyme-linked immunosorbent assay (ElISA). In: RAPLEY, R., WALKER, J. M. Molecular biomethods handbook. New Jersey : Humana, 1998. p.595618 .

HUDSON, L., HAY, F.C. Practical immunology. 3 ed. London: Blackwell, 1989. 507p.
LELLO, E., BOULARD, C. Rabbit antibody responses to experimental infestation with Dermatobia hominis. Medical and Veterinary Entomology, Oxford, v.4, n.4, p.303-309, 1990

LELlO, E., MOTA, N.G.S., PERAÇOLI, M.T.S. Reação inflamatória causada pelo berne, em coelhos imunizados ou não com extrato antigênico de Dermatobia hominis (Diptera: Cuterebridae). Ciência e Cultura, São Paulo, v.32, n.4, p.458-461, 1980 .

LELLO, E., PERAÇOLI, M.T.S. Cell-mediated and humoral immune responses in immunized and/or Dermatobia hominis infested rabbits. Veterinary Parasitology, Amsterdam, v.47, n.1-2, p.129-138, 1993.

LELLO, E., PINHEIRO, F.A., NOCE, O.F. Epidemiologia de miíases no Município de Botucatu, S. P., Brasil. Arquivo da Escola de Veterinária da Universidade Federal de Minas Gerais, Belo Horizonte, v.34, n.1, p.93-108, 1982.

MOTA, N.G.S., PERAÇOLI, M.T.S., LELLO, E. Anticorpos circulantes em coelhos imunizados com antígenos obtidos de larvas de Dermatobia hominis, Linnaeus (Diptera: Cuterebridae). Ciência e Cultura, São Paulo, v.32, n.4, p.453-457, 1980.

PERAÇOLI, M.T.S., LELLO, E., MOTA, N.G.S Comportamento da resposta imune-humoral em coelhos imunizados com antígenos de Dermatobia hominis Linnaeus, frente às larvas desse parasita (Diptera: Cuterebridae). Ciência e Cultura, São Paulo, v.32, n.11, p.1537-1541, 1980.

ROGAN, M.T. Immunological analysis of parasite molecules In: ROGAN, M. T. Analytical parasitology. Berlin : Springer-Verlag, 1997. Cap.10. p.320-359.

SANAVRIA, A., LOPES, C.W.G., MOYA BORJA, G.E. Histopatologia da pele de bovino na infecção experimental por Dermatobia hominis. Arquivos da Universidade Federal Rural do Rio de Janeiro, Itaguaí, v.10, n.1, p.9-23, 1987.

SÁNCHEZ-VISCAÍNO, J.M., CAMBRA-ALVAREZ, M. Enzyme immunoassay techniques, ELISA, in animal and plant diseases. 2 ed. Paris : O I E, 1987. 55p.

SANCHO, E. Dermatobia, the neotropical warble fly. Parasitology Today, Amsterdam, v.4, n.2, p.242-246, 1988.

SANDEMANN, R. W., CHANDLER, R. A., TURNER, N. $\boldsymbol{e}$ t al. Antibody degradation in wound exudates from blowfly infections on sheep. International Journal of Parasitology, Oxford, v.25, n.5, p.621-628, 1995.

SNEDECOR, G. W., COCHRAN, W. G. Statistical methods. 6 ed. Ames : Iowa, 1976. 593p.

TOMAN, K. Sensibilidad, especificidad y valor predictivo de los tests diagnosticos. Boletín de la Unión International contra la Tuberculosis, Köln, v.56, n.1, p.19-30, 1981. 